\title{
前方および下方への上肢の等尺性押し動作における 腹筋活動の分析
}

\author{
Abdominal Muscles Activities during Isometric Forward and Downward Pushing Tasks by \\ the Arms in the Sitting Position
}

中俣 修1) 金子 誠喜2)

\author{
OSAMU NAKAMATA ${ }^{1)}$, SEIKI KANEKO ${ }^{2)}$ \\ 1) Department Physical Therapy, Faculty of Health Science Technology, Bunkyo Gakuin University: 1196 Kamekubo, Hujimino- \\ city, Saitama 356-8533, Japan. TEL +81 49-261-7927 \\ 2) Graduate School of Human Health Sciences, Tokyo Metropolitan University
}

Rigakuryoho Kagaku 25(2): 291-297, 2010. Submitted Oct. 13, 2009. Accepted Nov. 24, 2009.

\begin{abstract}
Purpose] We investigated the trunk muscles, activities for stabilizing the spine against load by arm movement. [Subjects] Eight male subjects participated in this study. [Methods] Subjects performed 1) a pushing forward task (load perpendicular to the trunk) and 2) a pushing downward task (load parallel to the trunk) at different load magnitudes with isometric arm extension. Electromyography (EMG) of rectus abdominis (RA), oblique internus abdominis (OI), oblique externus abdominis (OE), lumbar mutifidus (LM), and longissimus thoracis (LT) were recorded with surface electrodes. [Results] Activity of RA, OE and OI increased with load magnitude in both tasks. RA was influenced by load direction. The activity of RA in the downward pushing task was larger than in the forward pushing task. Activities of LM and LT were influenced by load magnitude, but these muscles activities were low. [Conclusion] The RA muscle is the only muscle influenced by direction of load to the trunk.
\end{abstract}

Key words: trunk muscles, load direction, line of action

要旨：〔目的〕上肢運動の基盤を与える体幹部の姿勢保持に関わる体幹筋の活動を, 運動負荷の方向と体幹筋の作 用線方向の関係を考慮して筋電図学的に分析することを目的とした。〔対象〕健常男性 8 名を対象とした。〔方法〕 前方（体幹長軸に直交）および下方（体幹長軸に平行）への等尺性の上肢の押し動作を異なる運動負荷量で行わせ， その時の体幹筋の活動を表面筋電図を用いて計測した。運動負荷方向と運動負荷量の体幹筋活動量への影響を2元 配置分散分析により分析した。〔結果〕腹直筋，外腹斜筋，内腹斜筋の筋活動は，前方および下方への運動負荷方 向において運動負荷量に応じて増加した。腹直筋の筋活動には運動負荷方向の影響を認め, 前方への押し動作と比 較して下方への押し動作で大きかった。最長筋，多裂筋の筋活動には運動負荷量による相違を認めたが，その筋活 動は小さかった。〔結語〕腹直筋の筋活動には運動負荷方向の影響を認め, 作用線方向である体幹長軸方向へ作用 しやすい特徵をもつと考えられた。

キーワード : 体幹筋，運動負荷方向，筋の作用線

1) 文京学院大学＼cjkstart保健医療技術学部：埼玉県ふじみ野市亀久保1196（テ356-8533）TEL 049-261-7927

2) 首都大学東京 人間健康科学研究科

受付日 2009年10月13日＼cjkstart受理日２009年11月24日 


\section{I. 緒 言}

体幹には，その構えを様々に変化させる柔軟性と， 外力に応じて筋出力を発揮し体幹の姿勢の平衡状態を 維持する機能が要求される。安定した脊柱の状態を維 持するためには, 構造を静的・動的に支える骨, 勒帯 組織からなる脊柱, 脊柱を取り巻いて動的な安定性を 供給する筋，春柱の安定性を評価し筋の収縮応答を司 る神経系が, 協調的に作用することが必要である1)。骨, 勒帯組織のみでは動的に移り変わる姿勢を保持するた めの十分な安定性を得ることができないため, 動的な 安定性を供給する体幹筋の役割が重要と考えられてい る。

体幹筋の活動は, 姿勢はもとより運動課題により変化 する。しかしながら，立位や座位のように体幹を直立に した姿勢は, 姿勢保持に作用する筋活動が少なく2), 腹 筋群と背筋群のわずかな同時収縮により維持される3)。 一方, 押寸・引く・持ち上げるなどの上肢運動, 歩行 走行などの移動動作における下肢運動は, 姿勢の変化や 運動負荷の変化に応じて体幹の構えを制御するために体 幹筋の協調的な活動を必要と寸る。体幹筋の活動は, 運 動負荷の方向と筋の解剖学的な配置に大きく影響を受け る。そのため運動負荷方向と筋の配置さらには筋の作用 線方向の関係を分析することは, 筋運動の理解を深め対 象とした筋群の機能的な役割を明確にし, 臨床的には体 幹筋のトレーニング方法を決定する上で重要と考えられ る。

特定の運動方向への運動に対して共同的に作用する 筋群であっても解剖学的な筋の配置には相違がある。 そのため筋の作用線の関係から運動の主体を担う筋群 は変化すると考えられるにもかかわらず，運動学的な 筋の作用を中心に体幹筋の活動が分析されることが多 い。そのため体幹部に加わる運動負荷方向と筋の作用 線の関係を考慮した体幹筋活動の分析が求められるが, 筋の作用線方向との関係から筋活動の特徵を分析した 報告は少ない4)。

そこで矢状面における筋の作用線方向と運動負荷方 向との関係を図 1 のような解剖学的モデルとして考え た。腹直筋は体幹長軸に平行するため骨盤に対して胸 郭を下方に引き下げる出力成分を持つ。外腹斜筋は体 幹長軸に斜行するため骨盤に対して胸郭を前方に押し 出す出力成分と胸郭を下方に引き下げる出力成分に分 けることができる。内腹斜筋は体幹長軸に斜行するた め骨盤に対して胸郭を後方に変位させる出力成分と胸 郭を下方に引き下げる出力成分に分けることができる。

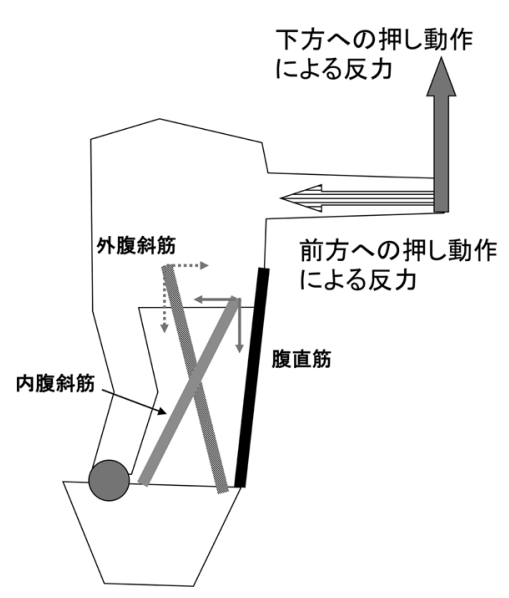

図1 体幹長軸に対する運動負荷方向 と筋の作用線の解剖学的モデル

そのため，1）腹直筋では下方への運動負荷方向で筋活 動が起こりやすく, 前方への運動負荷方向に対して筋 活動が起こりにくい。2）腹斜筋群では下方への運動負 荷方向に対して筋活動が起こりや寸く，3）前方への運 動負荷方向に対しては外腹斜筋の筋活動は起こりやす く, 内腹斜筋の活動は起こりにくい。また，姿勢を維 持するためには腹筋群の筋活動に対して拮抗筋である 背筋群の筋活動が必要と考えられるため, 4) 腹筋群の 拮抗筋である背筋群の筋活動は, 運動負荷方向に関わ らず腹筋群の筋活動に応じて増加する, と予想される。

そこで本研究では, 体幹長軸に平行または直交する 方向への上肢の押し動作を行わせた際の体幹筋の筋活 動を表面筋電図を用いて計測し，上肢運動の基盤とし て体幹部の姿勢保持に関わる体幹筋の筋活動を運動負 荷方向と体幹筋の作用線方向との関係を考慮して分析 することを目的とした。特に, 今回の運動課題で体幹 部の姿勢を保持するために必要となる腹筋群の機能を 中心に検討することとした。

\section{II. 対象と方法}

\section{1. 対象}

被験者は健常な大学生男性 8 名であった。被験者の 年齢, 身長, 体重の平均值（標準偏差）は，20.1 (1.4) 歳, 身長174.8（7.5） cm, 体重64.5（10.5） kg であった。 脊柱および上下肢に整形外科的な観血的治療の既往を 有する場合, 計測参加の2 ケ月以内に日常生活に困難を きたすような腰痛, 下肢のしびれなどの神経症状を有 する場合は被験者から除外した。本研究は, 首都大学 
東京研究倫理委員会の承認を得て, 被験者に十分な説 明を行った後，実験参加の同意を得て実施されたもの である。

\section{2. 方法}

体幹筋の筋電位の計測にはマルチテレメーターシス テム（WEB-5000, 日本光電社製）を用いた。体幹右側 の腹直筋, 外腹斜筋, 内腹斜筋, 多裂筋, 最長筋を対 象とした。皮膚研磨剤により皮膚処理を行いアルコー ル綿にて十分にふき取った後, 直径 $12 \mathrm{~mm}$ の円形銀-塩 化銀表面笳電図電極を電極中心間距離 $2 \mathrm{~cm}$ で貼付した。 電極貼付位置は過去の報告を参考に, それぞれ腹直筋 では臍部外側 $1 \mathrm{~cm}$ で正中より $2 \mathrm{~cm}$ 外側 ${ }^{5)}$, 外腹斜筋で は第11肋骨の前方と対側の恥骨結節を結ぶ線上で肋骨 縁下縁 ${ }^{5)}$, 内腹斜筋では左右の上前腸骨棘を結ぶ線の2 $\mathrm{cm}$ 下方で鼡径勒帯の内側6), 多裂筋では第 1 と第 2 腰椎 棘突起間と上後腸骨棘を結ぶ線上で第 5 腰椎棘突起の 2 $\mathrm{cm}$ 外側 5$)$, 最長筋では第 1 腰椎棘突起の $3 \mathrm{~cm}$ 外側 5$)$ とし た。基準電極は, 右外果に貼付した。

あらかじめ最大等尺性筋収縮（MVC）時の筋電図信 号の計測を次のように行った。腹筋群の計測姿勢は膝 立て背臥位（膝関節 90 度屈曲位）とし, 被験者の足部 を検查者が徒手的に固定した。被験者に両手を頭部後 面に当てた状態を維持させた。腹直笳の計測時には左 右の肩甲骨下角を離床させた体幹屈曲位を保持させ胸 骨上縁に徒手抵抗を加えた。腹斜筋の計測時には一側 の肘が反対側の上前腸骨棘に近づくように体幹の屈曲 回旋動作（外腹斜筋は左回旋, 内腹斜筋は右回旋）を 行わせ，肩甲骨の下角を離床させた体幹屈曲回旋位を 保持させ, 肩甲骨離床側の肩関節部前方に徒手抵抗を 加えた。多裂筋および最長筋の計測姿勢は腹臥位とし, 被験者の足部を検查者が徒手的に固定した。被験者に 両手を頭部後面に当てた状態を維持させ, 剣状突起部 を離床させた体幹伸展位を保持させ, 胸部上縁に徒手 抵抗を加えた。MVC計測時の課題保持時間は 3 秒間と し2回の計測を行った。

次に, 課題動作を以下のように行わせた。被験者は 筋力測定器 (Primus RS BTE 社製) の測定椅子上で背も たれを使用せず足部を離床した座位姿勢となり, 両大 腿遠位部はストラップにより固定された。被験者は両 側の肩関節を $90^{\circ}$ 屈曲位, 肘関節を $45^{\circ}$ 屈曲位とし両手 間の中心位置を胸骨頚切痕部の高さに合わせた筋力測 定器のレバーアームを両手で保持した。

課題を, 両上肢による筋力測定器のレバーアームの 等尺性の押し動作とした。上肢の押し動作により所定
の方向への体幹への運動負荷となるように, 体幹長軸 に直交する運動負荷方向への押し動作課題として 1$)$ 前 方への押し動作（以下，前方押し動作），体幹長軸に平 行する運動負荷方向への押し動作課題として2)下方 の押し動作（以下，下方押し動作）を実施した。この レバーアームに課題動作を行うことで押し動作の強さ が測定された。

各課題の運動負荷量を決定するため, レバーアーム バーを保持した安静状態での発揮張力を $0 \%$, 最大努力 での等尺性課題実施時の発揮張力を $100 \%$ とし, その 間に 4 段階（30，45，60，75\% Max）の相対的な運動負 荷量を設定した。各運動負荷方向を選択した後, 運動 負荷量をランダムに選択し, それぞれの組み合わせに 対して3回の測定を実施した。

被験者には, 課題実施中に胸腰椎部を中間位（肩峰 が大転子のほぼ鉛直上に位置し, 胸椎および腰椎が自 然に弯曲した状態）を維持するように指示した。また， 筋力測定器のモニター画面に表示される張力曲線を視 覚的に確認することにより，動作開始から約 2 秒間を かけて目標とした運動負荷量に達した後にその状態を 3 秒間保持し, 課題終了後にゆっくりと力を抜き安静状 態に戻るように指示を行った。押し動作課題の運動負 荷量として設定した相対的な運動負荷量（30，45，60, $75 \% \mathrm{Max}$ ）に対する実際の運動負荷量の平均值（標準 偏差）は，前方への押し動作課題では32.7（2.4），48.0 (2.1)，62.4（2.3），77.0（3.1）\%Max，下方押し動作課 題では32.2 (2.1), 46.3 (1.9), 60.4 (2.3), 73.9 (3.3)\% Maxであった。

筋電位信号を, 時定数 0.03 秒で低域遮断フィルタに より平滑化した後, A-D 変換器 (Power lab/16s, AD Instruments 社製）を介してサンプリング周波数 $1000 \mathrm{~Hz}$ にてコンピュータに取り込んだ。筋力測定器からの張 力信号は, 筀電位と同様に A-D 変換器を介してコン ピュータに取り込んだ。次にデータ処理ソフト (Chart3.5, $\mathrm{AD}$ Instruments 社製）を用いて，計測した筋電位信号に 対して帯域周波数20-450 Hzにてフィルタリング処理を 行い, MVC実施時の筋電位変化が比較的安定した領域, および課題実施時の発揮張力值が比較的安定した領域 から任意に 1 秒間の筋電位データを抽出した。表計算 ソフトMicrosoft Excelを用いて, 抽出したデータを全波 整流した後に積分筋電図值を算出した。課題動作時の 積分筋電図值をMVC時の積分筋電図值を用いて正規化 し, 積分筋電図值 (\%MVC) を算出し, 筋活動量の指 標とした。運動負荷方向と運動負荷量の各組み合わせ で得られた同一被験者の 3 回の測定值の平均值を分析 
表1 各筋における運動負荷方向および運動負荷量による筋活動量の変化

\begin{tabular}{|c|c|c|c|c|c|c|c|c|}
\hline \multirow{2}{*}{ 筋名 i } & \multirow{2}{*}{$\begin{array}{c}\text { 運動負荷 } \\
\text { 万向 }\end{array}$} & \multicolumn{6}{|c|}{ 運動負荷量 } & \multirow[t]{2}{*}{ 分散分析結果 } \\
\hline & & 負荷なし & $30 \% \mathrm{MAX}$ & $45 \%$ MAX & $60 \% \mathrm{MAX}$ & $75 \% \mathrm{MAX}$ & $100 \%$ MAX & \\
\hline \multirow[t]{2}{*}{ 腹直筋 } & 前方 & $0.9 \pm 0.4$ & $3.0 \pm 4.5$ & $5.8 \pm 6.3$ & $8.2 \pm 7.9$ & $11.2 \pm 8.8$ & $17.4 \pm 12.9$ & 運動負荷方向 $\times$ 運動負荷量 ** \\
\hline & 下方 & $0.9 \pm 0.5$ & $19.4 \pm 11.6$ & $31.6 \pm 16.4$ & $50.3 \pm 22.4$ & $62.6 \pm 21.0$ & $86.3 \pm 16.7$ & 運動負荷方向 ** 運動負荷量** \\
\hline \multirow[t]{2}{*}{ 外腹斜筋 } & 前方 & $2.3 \pm 1.4$ & $10.8 \pm 11.5$ & $16.8 \pm 12.1$ & $30.4 \pm 15.4$ & $42.3 \pm 17.8$ & $61.8 \pm 28.1$ & 運動負荷量 ** \\
\hline & 下方 & $2.2 \pm 1.1$ & $9.3 \pm 3.8$ & $17.8 \pm 5.9$ & $29.6 \pm 13.3$ & $43.9 \pm 19.5$ & $76.6 \pm 18.3$ & \\
\hline \multirow[t]{2}{*}{ 内腹斜筋 } & 前方 & $5.8 \pm 5.2$ & $11.5 \pm 9.3$ & $17.4 \pm 12.4$ & $30.6 \pm 26.5$ & $46.1 \pm 46.0$ & $54.3 \pm 34.2$ & 運動負荷量 ** \\
\hline & 下方 & $5.3 \pm 4.1$ & $9.8 \pm 4.2$ & $17.5 \pm 10.6$ & $25.2 \pm 10.1$ & $41.7 \pm 21.7$ & $76.8 \pm 35.7$ & \\
\hline \multirow[t]{2}{*}{ 最長筋 } & 前方 & $4.9 \pm 5.0$ & $4.9 \pm 5.1$ & $6.0 \pm 7.1$ & $6.7 \pm 6.1$ & $10.4 \pm 10.5$ & $10.1 \pm 5.1$ & 運動負荷量 ** \\
\hline & 下方 & $4.0 \pm 2.7$ & $3.1 \pm 1.6$ & $2.6 \pm 0.7$ & $3.2 \pm 0.7$ & $4.1 \pm 1.0$ & $5.7 \pm 1.8$ & \\
\hline \multirow[t]{2}{*}{ 多裂筋 } & 前方 & $5.8 \pm 3.0$ & $4.3 \pm 3.1$ & $5.4 \pm 2.7$ & $5.3 \pm 2.9$ & $6.9 \pm 4.6$ & $7.7 \pm 2.5$ & 運動負荷量* \\
\hline & 下方 & $5.6 \pm 3.4$ & $3.2 \pm 1.4$ & $3.2 \pm 0.7$ & $4.2 \pm 0.9$ & $5.6 \pm 1.6$ & $8.6 \pm 4.4$ & \\
\hline
\end{tabular}

平均值士標準偏差（単位：\%)

$\mathrm{n}=8$

$* * \mathrm{p}<0.01 * \mathrm{p}<0.05$

に用いた。

各筋の筋活動量に対する運動負荷方向と運動負荷量 の影響を分析するため，積分筋電図值（\%MVC）を従 属変数とし，運動負荷方向（前方および下方の 2 水準） と運動負荷量 $(0 ， 30,45,60,75,100 \% \operatorname{Max} の 6$ 水準) を要因とした繰り返しのある 2 元配置分散分析を用い た。分散分析の結果, 運動負荷方向と運動負荷量につ いて交互作用または各要因に主効果を認めた場合には, 各要因に対して下位検定を行った。運動負荷方向に主 効果を認めた場合には, 各運動負荷量における筋活動 量の相違の分析に対応のある $\mathrm{t}$ 検定を用いた。運動負 荷量に主効果を認めた場合にはBonferroni法による多重 比較検定を実施した。有意水準は5\%未満とした。

\section{III. 結 果}

前方および下方押し動作における各筋の筋活動量を 表 1 に, 運動負荷量の主効果に対する多重比較検定の 結果を表 2 に示した。分散分析の結果, 腹直筋の筋活動 量には, 運動負荷方向と運動負荷量の交互作用を認め $(\mathrm{F}(2,6)=27.1, \mathrm{p}<0.001)$, 運動負荷方向, 運動負荷量の 両方に主効果を認めた $(\mathrm{F}(2,6)=45.4, \mathrm{p}<0.001, \mathrm{~F}(2$, 6） $=71.5, \mathrm{p}<0.001 ） 。$ 運動負荷方向に主効果を認めたた め各運動負荷量において前方押し動作と下方押し動作 時の筋活動量を比較した結果, $0 \% \mathrm{Max}$ 以外の運動負荷 量において下方押し動作時の筋活動量が大きかった $(\mathrm{p}<0.01)$ 。運動負荷量の主効果に対する多重比較検定
の結果, 前方押し動作時の腹直筋の筋活動は安静状態 である $0 \% \operatorname{Max} と 75 ， 100 \% \operatorname{Max}$ 間に相違を認め，30〜 $75 \% \mathrm{Max}$ の運動負荷量では100\% Max とのみ相違を認め た。これに対し下方押し動作では運動負荷量の増加に 応じた筋活動の増加を認めた。

外腹斜筋および内腹斜筋の筋活動は, 前方押し動作, 下方押し動作のいずれにおいても運動負荷量の増大に 伴い増加した。分散分析の結果, 外腹斜筋の筋活動に おいては，運動負荷量の主効果が有意であった（F（2， 6) $=57.5, \mathrm{p}<0.001)$ 。同様に, 内腹斜筋の筋活動も, 運動 負荷量の主効果が有意であった $(\mathrm{F}(2,6)=20.0, \mathrm{p}<0.001)$ 。 多重比較検定の結果，外腹斜筋の筋活動は $60 \% \mathrm{Max}$ 以 上の運動負荷量, 内腹斜筋の筋活動は 75\% Max 以上の 運動負荷量にて, 安静状態である $0 \%$ Max と相違を認め た。

最長筋および多裂筋の筋活動は運動負荷量によらず 最大で $9 \% \mathrm{MVC}$ 程度の小さな筋活動レベルであった。分 散分析の結果, 最長筋の筋活動には運動負荷方向と運 動負荷量の交互作用を認めた（F $(2,6)=4.29, \mathrm{p}=0.039)$ が，運動負荷方向には主効果を認めず $(\mathrm{F}(2,6)=2.3, \mathrm{p}$ $=0.172 ）$ ，運動負荷量の主効果が有意であった（F（2, 6） $=6.4, p=0.007 ） 。$ 多裂筋の筋活動ついては運動負荷 量に主効果を認めた $(\mathrm{F}(2,6)=6.2, \mathrm{p}=0.019)$ 。多重比 較検定の結果, 最長筋の筋活動は前方押し動作では 0 , $30 \% \mathrm{Max}$ と 75，100\% Max 間で相違を認め，下方押し動 作では30，45，60\%Max と 100\%Max間に相違を認めた。 多裂筋の筋活動は前方押し動作では有意な相違を認め 
表2 運動負荷量による筋活動量の多重比較検定結果のまとめ

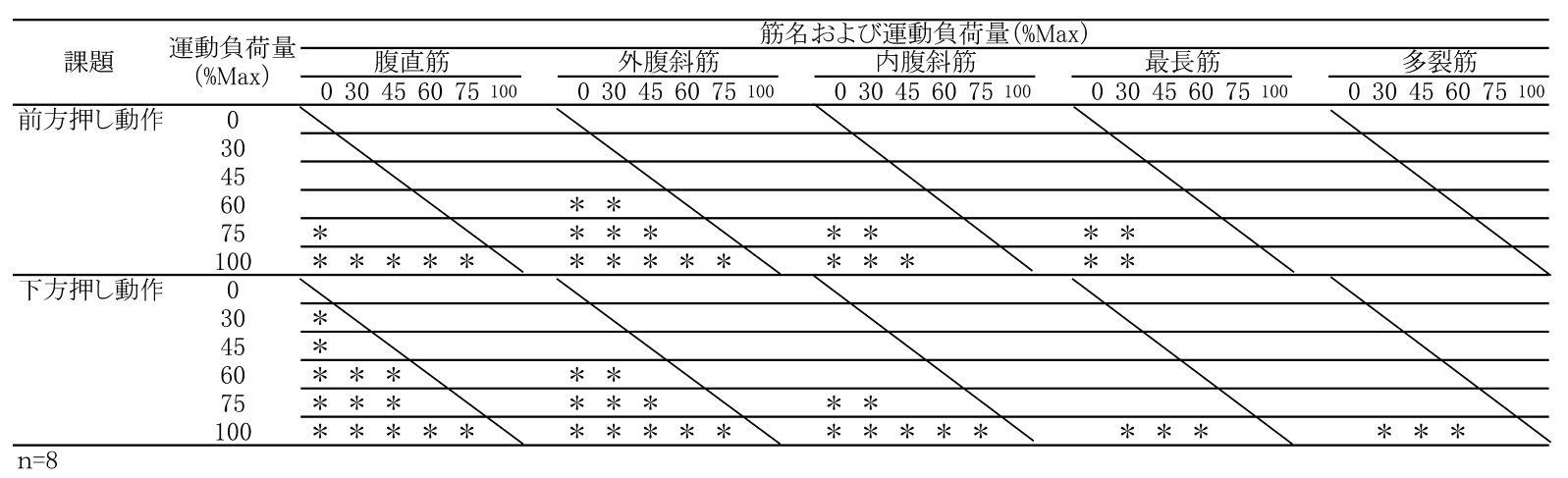

$* \mathrm{p}<0.05$

ず，下方押し動作の30，45，60\%Max と 100\%Max での み相違を認めた。

\section{IV. 考 察}

本研究では, 体幹筋の筋活動を分析するため表面筋 電図を用いた。表面筋電図による計測では隣接筋の筋 活動によるクロストークの影響を無視できない。外腹 斜笳を対象とした計測では, 深層の内腹斜筋, 腹横筋 の筇活動による信号の混入が考えられる。内腹斜筋は 外腹斜筋と腹横筋の中間層の筋であるが, 電極貼付部 位とした領域では外腹斜筋の等線維が存在しない腱膜 となっている領域である7)。このため内腹斜筋を対象 とした計測では, 外腹斜筇の筋活動の混入の影響を最 小限にできる部位とされるが, 一方で腹横筋の筋活動 による信号の混入が考えられる。McGill ら ${ }^{8)}$ は, 様々な 課題において表面筋電図とワイヤー筋電図の計測值の 関係を分析した結果, ワイヤー筋電図計測での外腹斜 筋, 内腹斜筋それぞれの筋活動は, 表面筋電図計測で の外腹斜筋, 内腹斜筋, 腹直筋の筋活動の全てと相関 を認めるものの, 表面筋電図計測による外腹斜筋, 内 腹斜筋の筋活動はワイヤー筋電図計測による外腹斜筋, 内腹斜筋の筋活動による信号を最も強く反映すると報 告している。多裂筋を対象とした計測では，表面筋電 図とワイヤー筋電図計測の計測值に相関を認めるとす る報告9) や, 表面筋電図とワイヤー筋電図の計測值に 相関を認めるものの最長筋からの筋活動をより反映す るという報告 ${ }^{10)}$ もある。以上のことから, 表面筋電図 による計測值は，隣接筋からのクロストークの影響を 含むものの, 計測筋の筋活動を反映しているものとし て結果を解釈した。

腹直筋の筋活動は運動負荷量に応じて増加していた。
分散分析の結果，筋活動量には運動負荷方向および運 動負荷量の影響を認めた。前方押し動作では, 運動負 荷量が大きい場合にのみ筋活動量の増加を認めたが, そ の活動量は最大運動負荷においても平均值で $16 \% \mathrm{MVC}$ と小さかった。下方押し動作では, 運動負荷量に応じ た段階的な筋活動の変化を認め, 最大運動負荷におけ る筋活動量は平均 $87 \% \mathrm{MVC}$ と前方押し動作と比較し大 きかった。腹直筋の筋活動には, 運動負荷方向による 相違を認め, 下方押し動作では運動負荷量に応じた段 階的な増加を認め, 前方押し動作と比較し高い筋活動 を認めた。これまでにも上肢による下方への押し動作 方向への等尺性運動（肩関節伸展運動）では, 腹直筋 に高い筋活動が生じることが示されている5,11)。これら のことから腹直筋が運動方向の特異性を持ち, 筋の作 用線に近い体幹長軸に平行する運動負荷方向で活動し やすいという特徴を持つことが再確認できた。

外腹斜筋および内腹斜筋の筋活動は運動負荷量に応 じて増加していた。分散分析の結果, 筋活動量には運 動負荷方向の影響を認めず，運動負荷量に影響を認め た。多重比較の結果，両課題ともに外腹斜筋では $60 \%$ Max 以上, 内腹斜筋では $75 \% \mathrm{Max}$ 以上の運動負荷量に おいて筋活動の増加を認めた。

腹斜筋の作用線方向と運動負荷方向の関係から，下 方押し動作では両腹斜筋の活動が，前方押し動作では 外腹斜筋の筋活動が起こりやすく, 内腹斜筋の活動は 起こりにくいと予測していた。しかし, 両腹斜筋の活 動には運動負荷方向の影響を認めなかった。上前腸骨 棘の下内側の部分とした電極貼付部位は, 内腹斜筋の 表面筋電図計測に用いられる領域で外腹斜筋の筋線維 が表層に存在しない7)。この領域の内腹斜筋線維は腸 骨稜および鼡径勒带から起こり内下方に走行し12), 腹 直筋腱膜に停止する。この横行する内腹斜筋および腹 
横筋は仙腸関節への圧迫力を加えることで骨盤を安定 させる役割を持つ13,14)。そのため筋の作用線方向が前 額面上に投影される部位であり，かつ胸郭部に直接的 な筋の付着を持たない領域であることから矢状面上の 解剖学的モデルとして考えた内腹斜筋の作用を捉える ためには適さなかった可能性がある。一方, 腹直筋腱 に付着するこの領域の内腹斜筋は, 胸郭および骨盤部 の直接的な運動に作用しないが，発生した力が腹直筋 腱膜を介して体幹屈曲力として伝達される ${ }^{15)}$ 。今回の 課題では，体幹部の姿勢を維持するために腹筋群によ る体幹屈曲力が要求される。前方押し動作では, 骨盤 に対して胸郭を前方に変位させるような腹筋群の作用 が必要となる。そのため筋の作用線方向の特徵から骨 盤に対して胸郭を後方に変位させる出力成分を持つ内 腹斜筋の筋活動が生じにくいと考えたが, 運動負荷量 の増加に応じて筋活動の増加を認めた。また, 運動負 荷量が増加した場合に腹直筋の活動も増加していた。 Callaghan $5^{4)}$ は，体幹への剪断負荷と圧迫負荷を加え る課題において腰椎に斜行し剪断力を生む背筋群と腰 椎に平行し圧迫力を生む背筋群が, 筋の作用線の特徵 のみに依存することなく伸展モーメントを発揮するよ うに活動することを報告している。今回の結果より腹 筋群の筋活動は，筋の作用線方向の影響を受けるもの の, 運動負荷の増加に伴い体幹屈曲力を高めるように 調整されると考える。

腹筋群と背筋群の同時収縮は体幹の安定性を高める ため, 腹筋群の筋活動量の増加に応じて背筋群の活動 が高まると予想した。分散分析の結果, 最長筋, 多裂 筋の筋活動には運動負荷量による影響を認めたものの, 両筋ともに筋活動量は少なく, 最大の運動負荷量でも 9\%MVC 未満であった。主動作筋である腹筋群の筋活 動量の変化と比較すると, 拮抗筋である背筋群の活動 量は小さく, 安静時の姿勢保持に働く筋活動とほぼ同 程度であった。McCookら 16) は, 座位姿勢において体幹 直立位を維持した状態で体幹長軸に直交するような伸 展方向の外力に対して腹筋群の筋活動量は増加するも のの, 背筋群の筋活動量の変化が小さく, 拮抗筋の筋 活動が増加しないことを報告している。今回の課題に おいても運動負荷量の増加に伴い腹筋の筋活動が増加 するものの背筋群の筋活動に大きな変化を認めなかっ た。この結果は, 姿勢を維持するための同時収縮の活 動レベルが拮抗筋間で異なることを示している。これ は腹筋群の筋活動に対して安静座位を保持する程度の 筋活動で姿勢が維持されるか, または拮抗筋間の筋活 動の相違があっても姿勢の平衡を維持するようなメカ
ニズムが作用することを示すものであり，今後の検討 が必要と考える。

筋の作用線方向と運動負荷方向の関係を考慮するこ とは，共同的な作用を持つ筋群において，より主体的 な役割を担う筋を明確にし，トレーニング方法の選択 に役立てることにつながると考えられる。そこで今回, 解剖学的モデルからの解釈から体幹への運動負荷方向 を変化させた際の腹筋群の筋活動について分析した。 その結果, 腹直筋は運動負荷方向の影響をうけること が明らかになった。これは運動負荷方向を規定するこ とにより腹直筋の筋活動量を減少させることができる ことを示しており，体幹筋のトレーニング方法を検討 する上で重要と考えられる。

本研究では体幹長軸に直交または平行する運動負荷 方向について限定して検討を行った。実際には, 上肢 運動を用いた体幹筋トレーニング動作, 車椅子移動介 助時や荷物運搬車による運搬作業など，体幹に対する 上肢の押し動作出力方向が大きく変化することが多い。 このため中間的な運動負荷方向についても検討し，運 動負荷方向と筋の作用線との関係から体幹筋の筋活動 について分析することが有益と考える。

\section{引用文献}

1) Panjabi MM: Clinical spinal instability and low back pain. J Electromyogr Kinesiol, 2003, 13: 371-379.

2) Juker D, McGill S, Kropf P, et al.: Quantitative intramuscular myoelectric activity of lumbar portions of psoas and the abdominal wall during a wide variety of tasks. Med Sci Sports Exerc, 1998, 30: 301-310.

3) Cholewicki J, Panjabi MM, Khachatryan A: Stabilizing function of trunk flexor-extensor muscles around a neutral spine posture. Spine, 1997, 22: 2207-2212.

4) Callaghan JP, McGill SM: Muscle activity and low back loads under external shear and compressive loading. Spine, 1995, 20: 992-998.

5) Tarnanen SP, Ylinen JJ, Siekkinen KM, et al.: Effect of isometric upper-extremity exercises on the activation of core stabilizing muscles. Arch Phys Med Rehabi, 2008, 89: 513-521.

6) White SG, McNair PJ: Abdominal and erector spinae muscle activity during gait: the use of cluster analysis to identify patterns of activity. Clin Biomech, 2002, 17: 177-184.

7) $\mathrm{Ng} \mathrm{JK}$, Kippers V, Richardson CA: Muscle fibre orientation of abdominal muscles and suggested surface EMG electrode positions. Electromyogr Clin Neurophysiol, 1998, 38: 51-58.

8) McGill S, Juker D, Kropf P: Appropriately placed surface EMG electrodes reflect deep muscle activity (psoas, quadratus lumborum, abdominal wall) in the lumbar spine. J Biomech, 1996, 29: 1503-1507. 
9) Arokoski JP, Kankaanpää M, Valta T, et al.: Back and hip extensor muscle function during therapeutic exercises. Arch Phys Med Rehabil, 1999, 80: 842-850.

10) Stokes IAF, Henry SM, Single RM: Surface EMG electrodes do not accurately record from lumbar multifidus muscles. Clin Biomech, 2003, 18: 9-13.

11) Arokoski JP, Valta T, Kankaanpää M, et al.: Activation of lumbar paraspinal and abdominal muscles during therapeutic exercises in chronic low back pain patients. Arch Phys Med Rehabil, 2004, 85: 823-832.

12) Urquhart DM, Barker PJ, Hodges PW, et al.: Regional morphology of the transversus abdominis and obliquus internus and externus abdominis muscles. Clin Biomech, 2005, 20: 233-241.
13) Snijders CJ, Ribbers MT, de Bakker HV, et al.: EMG recordings of abdominal and back muscles in various standing postures: validation of a biomechanical model on sacroiliac joint stability. J Electromyogr Kinesiol, 1998, 8: 205-214.

14) Richardson CA, Snijders CJ, Hides JA, et al.: The relation between the transversus abdominis muscles, sacroiliac joint mechanics, and low back pain. Spine, 2002, 27: 399-405.

15) McGill SM: A revised anatomical model of the abdominal musculature for torso flexion efforts. J Biomech, 1996, 29: 973-977.

16) McCook DT, Vicenzino B, Hodges PW: Activity of deep abdominal muscles increases during submaximal flexion and extension efforts but antagonist co-contraction remains unchanged. J Electromyogr Kinesiol, 2009, 19: 754-762. 